\title{
平成21年7月洪水における佐波川の 水収支と土砂収支について ON FLOW AND SEDIMENT BALANCE OF FLOOD IN SABA RIVER OCCURRED ON JULY, 2009
}

\author{
朝位孝二 1 ・高崎敦彦 $2 \cdot$ 萬運 $3 \cdot$ 今津勉 4 \\ Koji ASAI, Atsuhiko TAKASAKI, Hakobu YOROZU, Tsutomu IMAZU \\ 1正会員 博士（工） 山口大学准教授 理工学研究科（テ755-8611 山口県宇部市常盤台2-16-1） \\ 2正会員 工修 東亜建設技術株式会社 設計計画チーム（†819-0046 福岡県福岡市西区西の丘1-7-1） \\ 3正会員 東亜建設技術株式会社＼cjkstart設計計画チーム（广819-0046 福岡県福岡市西区西の丘1-7-1） \\ 4非会員 国土交通省山口河川国道事務所 河川管理課（干747-8585 山口県防府市国衙1-10-20）
}

\begin{abstract}
A flood occurred in Saba River which passes through Hofu City, Yamaguchi due to heavy rainfall on 21st July, 2009. The rain induced slope failure and caused a large quantity of sediment to flow into the river. In this study, the estimation of the flow balance and the sediment balance were conducted by using numerical simulation and the river bed elevation data observed before and after the flood.

The numerical simulation for the flow balance in which the inflow discharge from the branch rivers and the overflow from a bank are considered is in good agreement with the observed hydrograph at the Shinbashi station. Although the numerical simulation overestimates the volume of the sediment accumulated in the river, the accumulation properties in the river can be simulated qualitatively.
\end{abstract}

Key Words : Saba River, heavy rainfall in 2009, flow balance, sediment balance, River bed variation

\section{1. はじめに}

平成21年7月21日の豪雨により，山口県防府市では大 規模な土砂災害が発生し，防府市内で13名（山口県全体 で17名）の犠牲者が発生した ${ }^{1), 2)}$ ．防府市を貫流する一 級河川である佐波川では破堤は生じなかったものの，河 道の断面不足の箇所や無堤部において河川より堤内地一 の氾濫が生じたが，幸いにもこの汇濫による人的被害は 生じていない，流域内では複数の山腹崩壊が生じており, 大量の土砂が河川内に流入した．後述するように，洪水 後に実施された測量成果によれば，洪水後の河床は全体 的に堆積傾向にある3).

ところで，佐波川では今後の河川整備として，洪水流 下の阻害となっている固定堰の撤去および堰の統廃合を 進めている. 平成21年7月洪水時点では, 二つの固定堰 を統廃合し可動堰とする事業が完了していたが，平成21 年7月洪水後，とくにこの可動堰の上下流で大量の土砂 堆積が生じており ${ }^{3)}$ ，今後も土砂堆積が進行するようで あれば，可動堰のゲート機能に支障を来す恐れがある.

現況の佐波川では, 河積が不足している箇所があり,
また固定堰が多いことから，堰の統廃合および可動堰化 は佐波川の治水能力を向上への有効な手段である. しか し, 河川管理施設の適切な維持管理・運用を図るために は, 新しい堰周りの堆積・洗掘特性や堰撤去箇所の河道 の安定性などの課題をクリアする必要がある.

三輪" は事例をもとに可動堰地点の河床の堀下げが, 土砂堆積の原因であると指摘している。福岡ら5)は固定 堰の可動堰化に伴う河床一の影響について，堰上下流を 対象として，河床モニタリングを行い，出水時における 堰上下流の土砂移動について検討している.

著者らは佐波川の堰の統廃合が河道安定特性に及ぼす 影響ついて明らかにし，問題があればその対策について 検討することを目的として研究・調查を行っているが, 佐波川で平成21年7月21日に発生した洪水では，支川か らの土砂流入が顕著であり, 堤防高不足による越水や支 川処理のない箇所で内水が発生しているため, これらの 影響を考慮した河床変動計算を行う必要がある.

本研究では，このような現象に配慮し，越水・内水を 考慮した水収支モデルを構築し，その結果をもとに支川 の土砂流入を考慮した河床変動計算を実施し，佐波川の 水収支，土砂収支および河床変動について検討した。 


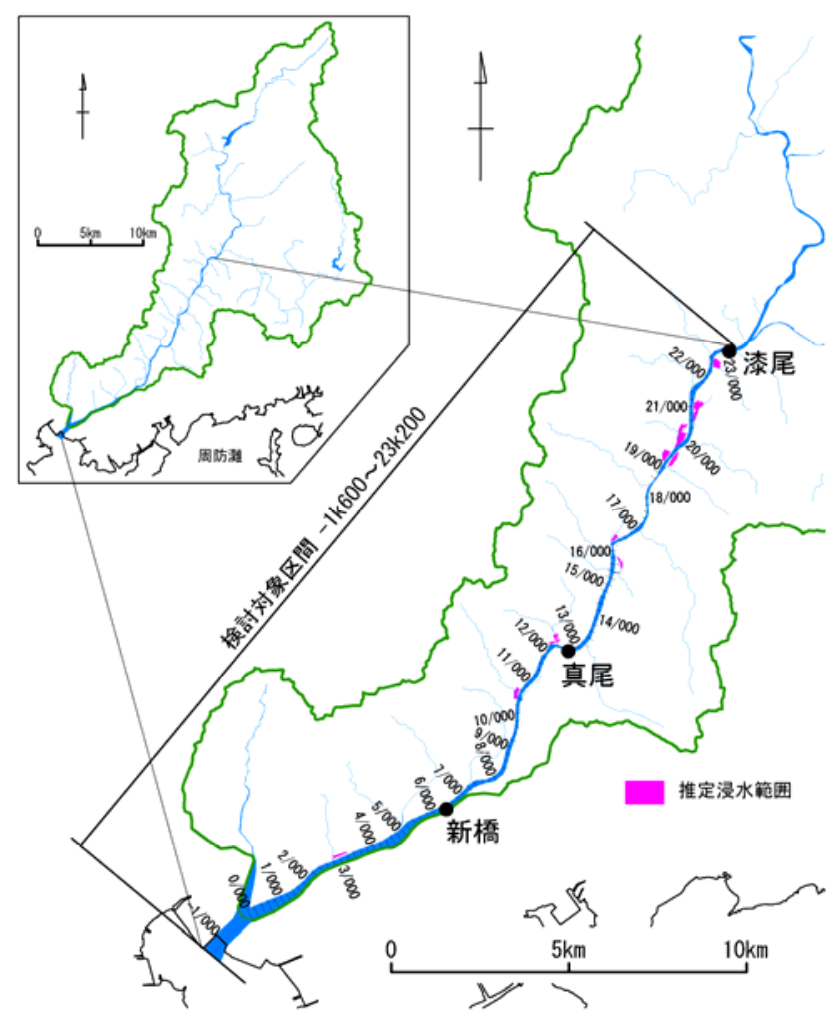

図-1 佐波川流域図

\section{2. 佐波川の概要}

佐波川は，山口県・島根県境の三ツヶ峰に発し，山間 峡谷部を流れ，防府市を経て周防灘に注ぐ流域面積 $460 \mathrm{~km}^{2}$, 幹川流路延長 $56 \mathrm{~km}$ の一級河川である。 その流 域図を図-1に示す，河口から直轄区間の上流端である 26k200地点の内, 約83.2\%が河床勾配1/1000以上であり, 4k266地点に位置する佐野用水堰より上流は河床勾配が 1/550以上の急流河川となっている.

佐波川直轄区間には16基の堰が存在していたが，平成 19年度に金波堰（10k483地点）と峪堰（11k883地点）が 撤去され，新たに上右田堰（11k745地点）が竣工し，現 在は15基となっている．直轄区間 $26.2 \mathrm{~km} に 15$ 基という多 くの堰が存在していることも佐波川の特徴の一つである.

\section{3. 水収支モデル}

\section{（1）水収支モデル}

\section{a) モデルの概要}

平成 21 年 7 月洪水における水収支を明らかにするた め, 支川合流部における河道から堤外地一の流入や，堤 防高が不足している地点における越流を考慮した水収支 計算モデルを構築した. 河道の水位は 1 次元非定常計算 法で算定した. 内水による支川流入量の低減を考慮する

ため，背水堤や水門等の支川処理がない支川の合流部に ポンドを設け, 河川とポンドとの水位差から流量のやり とりを行うものとした (図-2 参照). 河川水位が堤防を 上回る箇所については，越水を考慮した．また，河川と ポンドとの流入出量の算定には本間の公式を用いた. 越 水量の算定には本間の公式から算定した越流量に河床勾 配をパラメータとする横越流の補正式を適用した ${ }^{6}$.

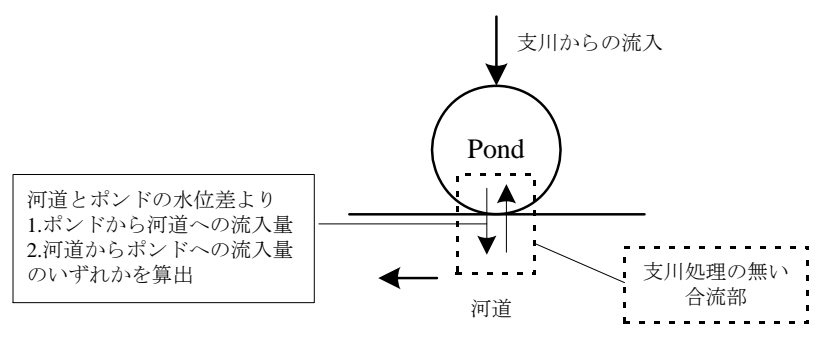

図-2 河道〜ポンド流入出量算定手法

\section{b) 計算条件}

計算対象区間は河口（-1k600地点）から漆尾観測所 （23k200地点）とした．境界条件は，上流端には漆尾観 測所で観測された実測流量を与え，下流端では佐波川河 口に最寄りの三田尻中関港の調和定数から天文潮位を求 め，それを与えた。 図-3に両境界条件と真尾観測所の雨 量を示寸. 河道の横断形状は, 平成21年7月洪水前の平 成20年に実施された定期縦横断測量成果を用いた.

支川からの流入量は，直列3段のタンクモデルを用い て算定した. 対象流域の地質は花崗岩であるため, モデ ルパラメーターはIshihara and Kobatake ${ }^{7)}$ が花崗岩地帯で 提案している值を採用した. 表-1にタンクモデル定数を 示す. 雨量データは流域内に位置する真尾観測所 （12k700地点）の1時間雨量データを用いた。計算は, タンクモデルの助走期間を考慮し, 検討対象洪水の約 2ヶ月前から実施した。計算期間は平成21年7月20日から 7月22日までの3日間とし，内水による支川流入量の低減 および越流を考慮した場合（Case1）と，これらの効果 を考慮しない場合（Case2）の2ケースで計算を実施した.

\section{（2）観測流量と計算流量の比較}

真尾観測所および新橋観測所（6k400地点）における 観測流量と計算流量の比較をそれぞれ，図-4および図-5 に示す. 真尾観測所地点におけるCase1でのピーク流量 は, 観測值 $1,305 \mathrm{~m}^{3} / \mathrm{s}$ に対し, 計算值は $1,303 \mathrm{~m}^{3} / \mathrm{s}$ であり非 常に良く一致している. 一方, 20日18:00時頃からピー ク流量時までの増水期間では計算値は多少過大評価気味 ではあるが，多大な相違は見られない．減水期では22日 0:00時までは良好な一致を示しているが，その時刻以降 では計算值は過大評価となっている。

Case1での新橋観測所地点における計算流量波形も真 尾と同様の傾向が見られるが，減水期の再現性は真尾よ りも良好である。ピーク流量は観測值 $1,253 \mathrm{~m}^{3} / \mathrm{s}$ に対し, 


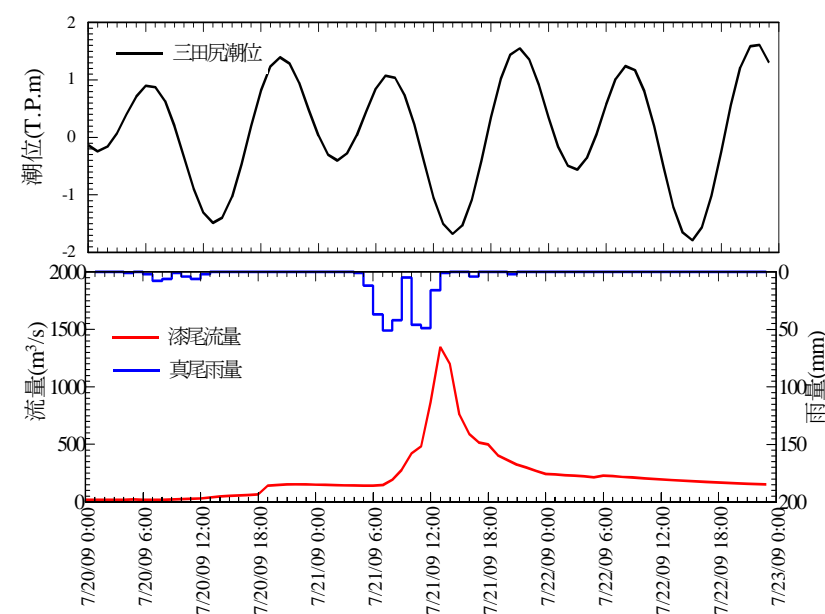

図-3 下流端水位と上流端流量

表-1タンクモデル定数

\begin{tabular}{cccc}
\hline & 上段 & 中段 & 下段 \\
\hline $\begin{array}{c}\text { 流出孔の高さ } \\
(\mathrm{mm})\end{array}$ & $\begin{array}{c}L_{1}=15 \\
L_{2}=60\end{array}$ & $L_{3}=15$ & $L_{4}=15$ \\
\hline 流出係数 $(1 / \mathrm{hr})$ & $\begin{array}{l}\alpha_{1}=0.10 \\
\alpha_{2}=0.15\end{array}$ & $\alpha_{3}=0.05$ & $\alpha_{4}=0.01$ \\
\hline 浸透係数 $(1 / \mathrm{hr})$ & $\beta_{1}=0.12$ & $\beta_{2}=0.05$ & $\beta_{3}=0.01$ \\
\hline
\end{tabular}

計算值は $1,320 \mathrm{~m}^{3} / \mathrm{s}$ であり，真尾の場合と比較すると，誤 差は大きいが，比較的良い再現性があると言えよう。全 体的には，真尾においても新橋においても計算值は実測 值と良い一致を示していると言える.

一方，Case2では，両観測所ともにピーク流量が過大 評価されていることが一目瞭然である.このことから， 今回の洪水の解析では内水による支川流入量の低減およ び越流量を考慮しなければならいない事が明らかとなっ た.

流入（流出）流量の 21 日0:00～22日0:00間での積分を 洪水期間の流入（流出）体積と定義し, 流入（流出）体 積の収支を検討する. 図-6に得られた結果を示す。上流 境界である漆尾では3,583万 $\mathrm{m}^{3} の$ 流入があった．支川か らの流入量は2,023万 $\mathrm{m}^{3}$ ，本川からの越水による流出量 は311万 $\mathrm{m}^{3}$ であった. 支川からの正味の流入量は1,712万 $\mathrm{m}^{3}$ となり, 漆尾の流入量の $48 \%$ に相当する量である. 河 口での流出量は5,016万的である。 これらから，河道内 貯留量は279万的光と推定される.

\section{（3）痕跡水位との比較}

図-7に平成21年7月洪水の痕跡水位と，洪水前の平成 20年および洪水後の平成21年の河道形状での水収支モデ ルによる計算水位を示す，痕跡水位と計算水位は比較的 よく一致しており，水位の再現性はよい，堰統廃合区間 の周辺（10k200地点～12k400地点）では河床変動が顕著 であるため，洪水前後で計算水位が異なり，上右田堰上 流の痕跡水位は，洪水前の河道の計算水位の方が適合性

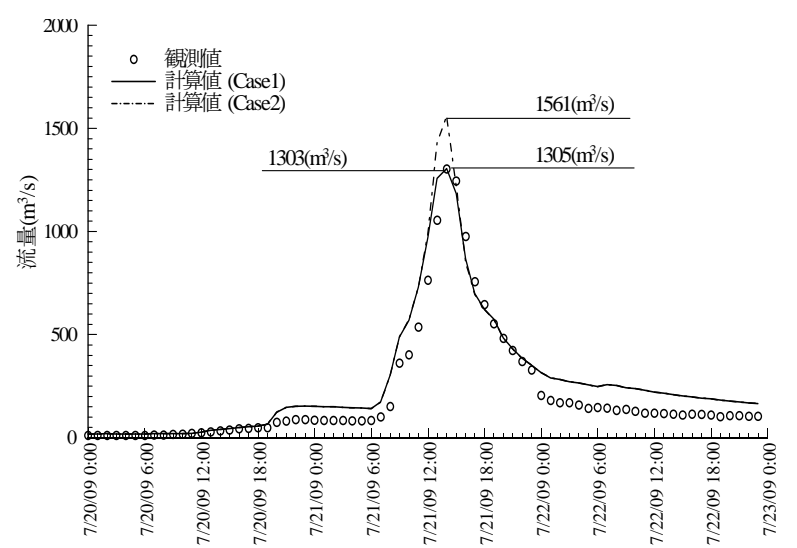

図-4 流量波形の計算值と観測値の比較（真尾観測所）

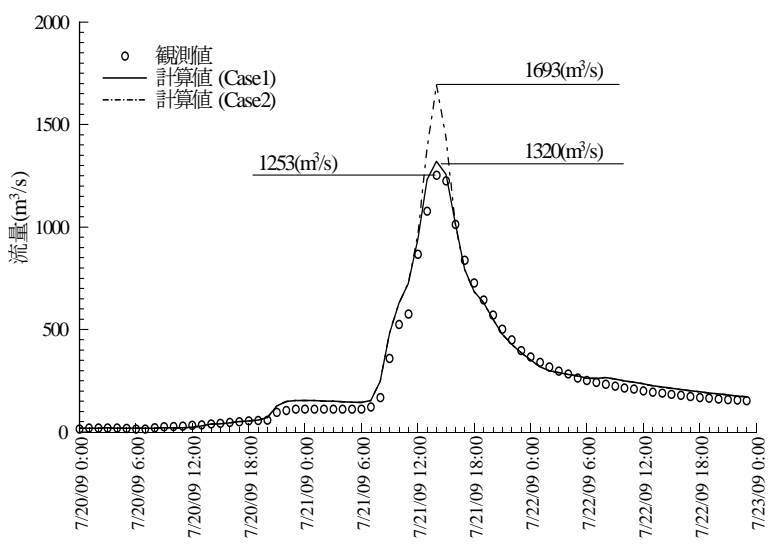

図-5 流量波形の計算値と観測値の比較（新橋観測所）

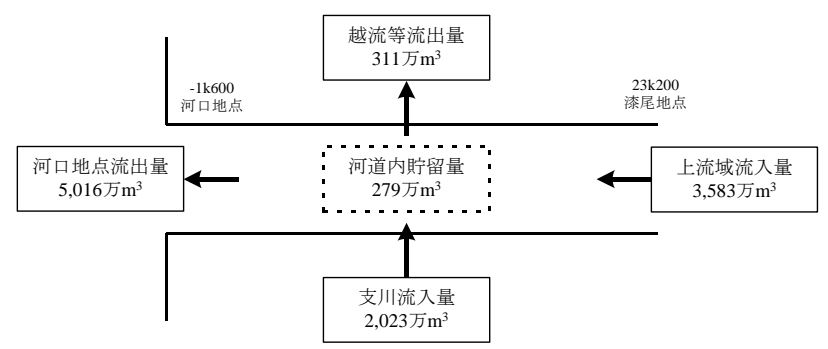

図-6 洪水期間の水収支

がよい，堤防高よりも計算水位が高い箇所は，越水によ る汇濫が生じており，その箇所は図-1の推定浸水範囲の 箇所とよく一致している.

\section{4. 河床変動計算}

\section{（1）平成21年洪水前後の河床変動}

図-9に河道断面積の変動量を示寸. 河口から $1 \mathrm{k} 800$ 地 点の区間では河口近傍で堆積傾向にあるが，その上流で は洗掘傾向にある. 佐野用水堰（4k266地点）の上流で は堆積傾向にある.これは剣川からの山腹崩壊で生じた 土砂流入の影響や堰による湛水の要因が考えられる.

堰統廃合事業のため，平成19年に撤去された旧金波堰 および旧峪堰では，ともに堰上流で洗掘傾向，堰下流で 


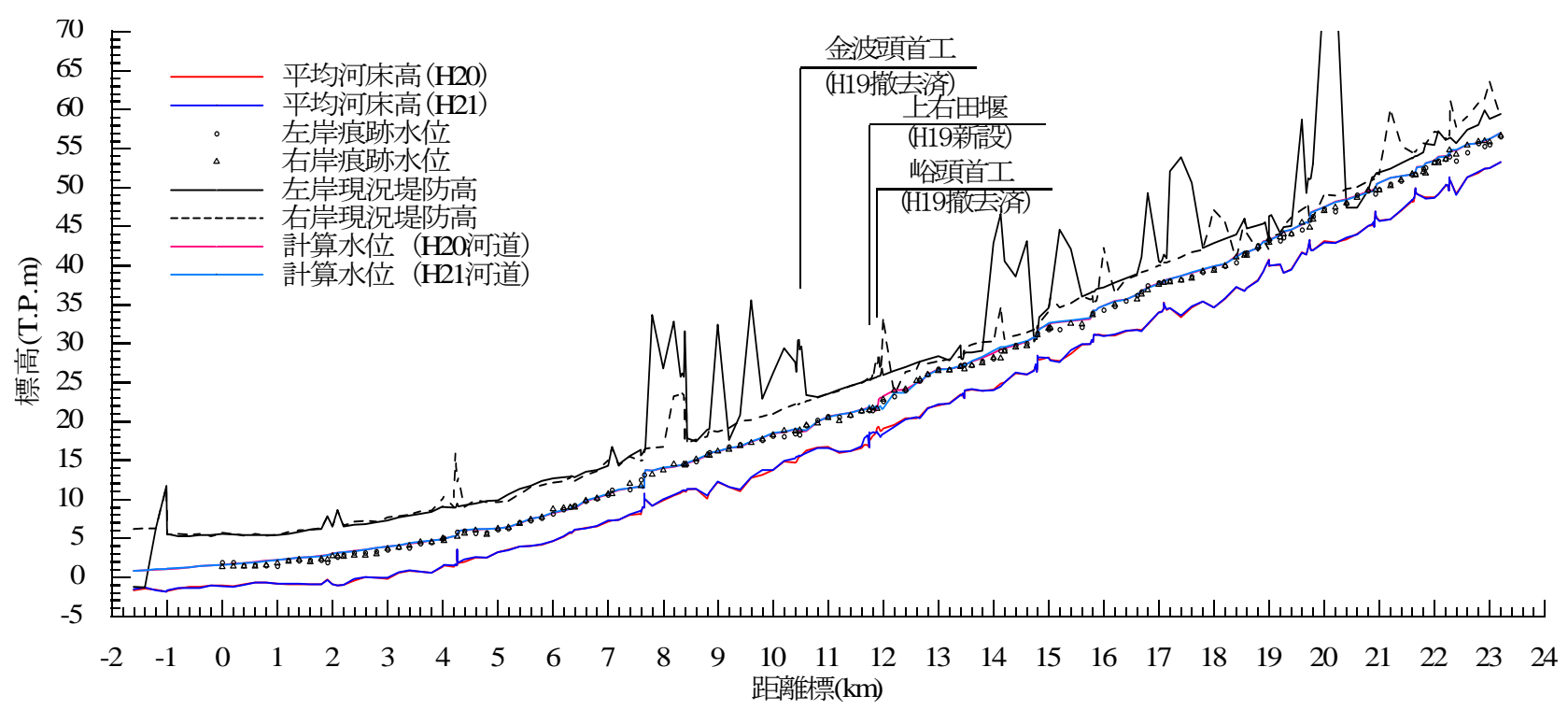

図-7＼cjkstart痕跡水位および計算水位縱断図

は堆積傾向が見られ，旧峪堰の直下にある可動堰の上右 田堰の上下流では堆積傾向が顕著である.

\section{（2）計算手法}

河床変動計算は，複断面形状を考慮した準2次元不等 流計算 ${ }^{8)}$ によその時刻における各計算断面の水理量を 算定し，この水理量を用いて各計算断面の流砂量（掃流 砂量および浮遊砂量）の算定を行った後，流砂量の連続 の式により河床高の変動を算定する．掃流砂量および浮 遊砂量の算定には，ともに芦田・道上の式を用いた。河 道断面は，横断方向に $5 \mathrm{~m} ヒ ゚ ッ チ の$ 矩形形状でモデル化 した（図-8参照）。河床の変動が発生する区間（主に低 水路）を河床変動域とし，それ以外については河床変動 しないものとした．横断面内固定堰や岩が露出している 断面は，固定床として取り扱い河床の低下は生じないも のとした．また，固定堰の堰頂では河床の上昇も生じな いものとした.

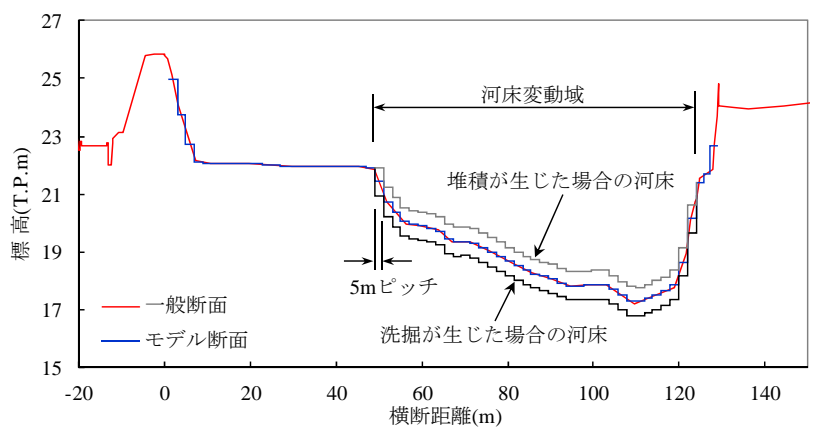

図-8＼cjkstart河道断面のモデル化

\section{（3）計算条件}

下流端の境界条件は，水収支モデルと同じく三田尻中 関港の潮位を与えた。河道流量は水収支モデルの計算結 果を基本としたが，水収支モデルが非定常計算であるの に対し，河床変動計算は定常計算であるため，区間毎に
流量を与える必要がある，そこで，対象区間を流量の最 大值が概小等しい区間に15分割し，この分割した区間の 各地点における流量波形を平均化したものを各区間にお ける流量波形として与えた.

平成21年7月洪水では，大量の土砂が河道へ流入して いるため，洪水前後の土砂収支を検討するには，支川か らの土砂流入量を考慮する必要がある．洪水前後の調査 では，山腹崩壊があった支川を対象とした航空レーザ計 測データ（地表面標高データ）の差から，河道への土砂 流入量の総量をおよそ $120,000 \mathrm{~m}^{3}$ と推測している9 . しか しながら，崩壊が発生した時刻や時系列的な土砂流入量 に関する知見は得られていない，そこで，今回は山腹崩 壊があった支川を対象に，流量に対して一定濃度で土砂 が混入するものと仮定した. 混入濃度を種々変えて計算 を行ったところ，支川流量の $0.3 \%$ を砂流入量として与 えた場合が最も良い結果を得た。

河床材料の粒度分布は，平成21年7月洪水前の直近の 調査である平成 9 年および平成11年の河床材料調査の成

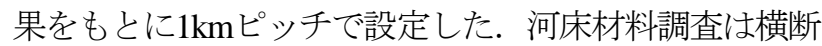
方向に左岸，中央，右岸で実施されているが，澪筋にあ たる地点の粒度分布を採用した．粒度分布は $0.0075 \mathrm{~cm}$ ら25cmまで20階級に分割した。

\section{（4）河床変動の比較と土砂収支}

図-10に平均河床高変動量の計算值と実測值を示す. 洗掘・堆積の度合いが大きく異なる箇所が堰の上下流で 見られる.これは，粒度分布を $1 \mathrm{~km}$ ピッチの河床材料調 査結果を適用しているため, 堰上下流の粒度分布の違い を考慮していないことなどが原因と思われる.

8k000地点から10k000地点の区間では，実測值が堆積 傾向にあるのに対し，計算值では洗掘傾向にある。この 区間では堤防沿いに樹林化した砂州が形成されており， この砂州において堆積が生じ，低水路では洗掘が生じて 


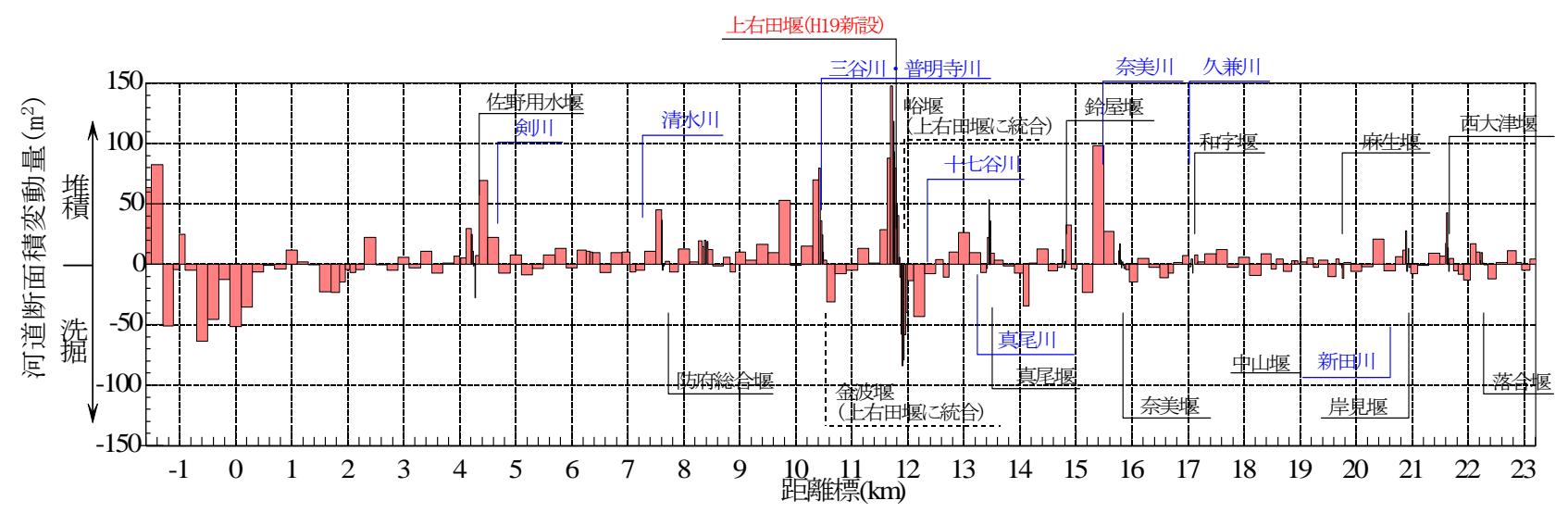

図-9 平成21年7月洪水前後の河道断面積変動量

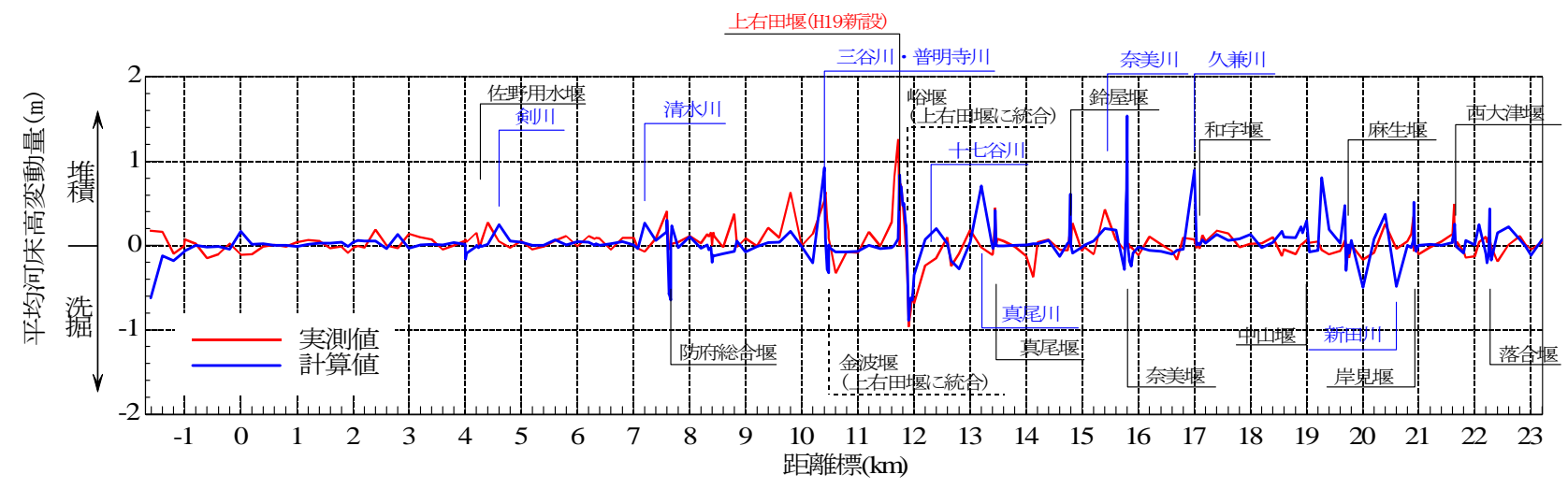

図-10 平均河床高変動量の比較

いる. 河床変動計算は準2次元不等流計算によって高水 敷・低水路・樹木群等の分割断面毎に水理量を算定して いるが，河床変動に用いる水理量は，分割断面毎の水理 量を井田の断面分割法 ${ }^{10)}$ により合成して使用している. そのため，この区間のような断面内で流速分布が卓越す る場合は計算結果との整合しないものと考えられる．図 -11 (a) に11k943地点における平成20年，平成21年の実測 值と計算值の横断面図を示した. このように河床が一様 に変動する地点においては, 河床変動計算の再現性はよ い.しかし，図-11 (b)に示寸ように，同じ断面内におい て，樹木の繁茂した領域にのみ著しく堆積が進行し，河 床が一様に変動していない地点では河床変動計算の再現 性はよくない。

支川からの流入土砂を考慮した剣川，三谷川・普明寺 川, 真尾川, 奈美川合流点において, 河床の堆積傾向が 再現されている. 河口部では河床変動の傾向が異なって いる．河口部では流量とともに，潮位によって流れが規 定されるため, より詳細な検討が必要であると思われる.

図-12に堰統廃合事業区間における計算值と実測值の 平均河床高縦断図を示す，旧峪堰の撤去により，河道の 安定性が崩れ, 旧峪堰上流の河床が洗掘され, 上右田堰 の区間で堆積している状況をよく再現している. 上右田 堰の下流では，実測值で約 $1.3 \mathrm{~m} の$ 河床の上昇が見られる が，計算值ではそれほど河床の上昇は見られない，上右 田堰は高さ3.15mのゲートを有する可動堰であるが，今

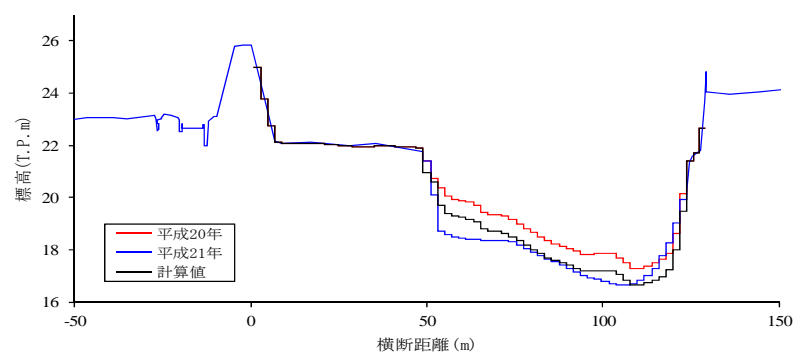

(a) $11 \mathrm{k} 943$ 地点

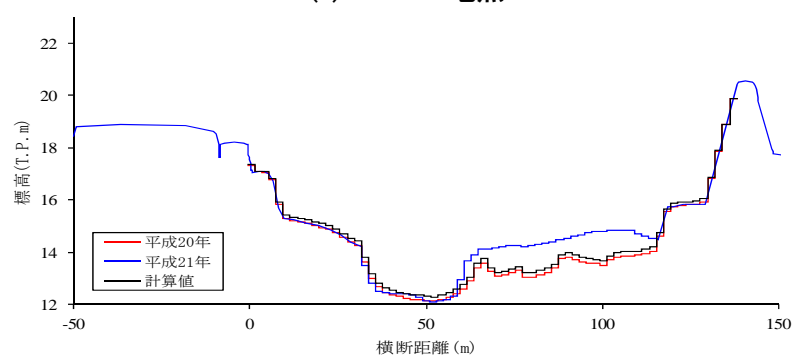

(b) $9 \mathrm{k} 800$ 地点

図-11 河道断面の比較

回の計算は，計算初期よりゲートは完全に倒伏している と想定して実施した．洪水時のゲート操作が堰下流にお ける河床上昇に影響している可能性も考えられる．ゲー 卜操作が河床変動に及ぼす影響については今後の研究課 題としたい.

図-13に河床変動量を上流端から累加した值を縦断的 に表示した結果を示す. 10k000地点付近では, 実測值, 計算值ともに約 $40,000 \mathrm{~m}^{3}$ 程度であり, オーダー的に一致 


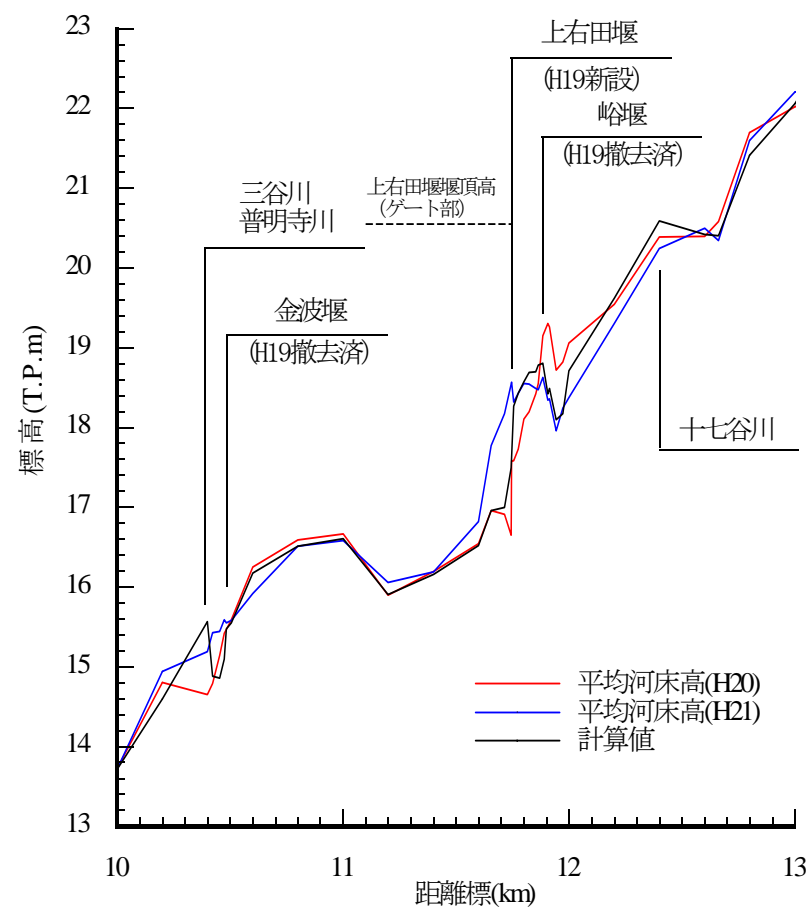

図-12 平均河床高の比較

している。しかし，河口部では，実測值で約 $60,000 \mathrm{~m}^{3}$ ， 計算值で約20,000 $\mathrm{m}^{3}$ と大きく乘離している．これは，前 述したとおり河口部における河床変動の傾向が異なるこ とや，樹木群の卓越する区間における河床変動の傾向の 乘離などが原因と考えられる．参考として図-13に上述 した8k000〜10k000区間の河床変動量を除いた累加図も あわせて示した８k000下流でも計算結果の河床変動量 は実測值のそれとよく合致することがわかる.

\section{5. 結論}

本研究で得られた主要な結論を以下に示す.

1）支川からの流入量の低減および堤防からの越水を 考慮した水収支モデルにより再現した計算結果は, 平成21年7月洪水時の流量波形および㢃跡水位と良 く一致している.

2）洪水期間の水収支として，21日0:00〜22日0:00間に， 上流境界である漆尾から 3,583 万 $\mathrm{m}^{3}$ の流入，支川か ら2,023万 $\mathrm{m}^{3}$ の流入, 越水による311万 $\mathrm{m}^{3}$ の流出, 河口から5,016万 $\mathrm{m}^{3}$ の流出が評価された.

3）水収支モデルの計算結果をもとに，支川からの土 砂流入を考慮した河床変動計算を実施した，その 結果，洗掘・堆積の度合いの違い，斜め堰上下流， 樹木群が繁茂する区間および河口部等において傾 向の違いが見られたが，河床変動および土砂収支 の傾向を概ね再現している.

4）特に河床変動が顕著であった堰統廃合区間では, 固定堰撤去に伴って不安定化した堰上流の河道が

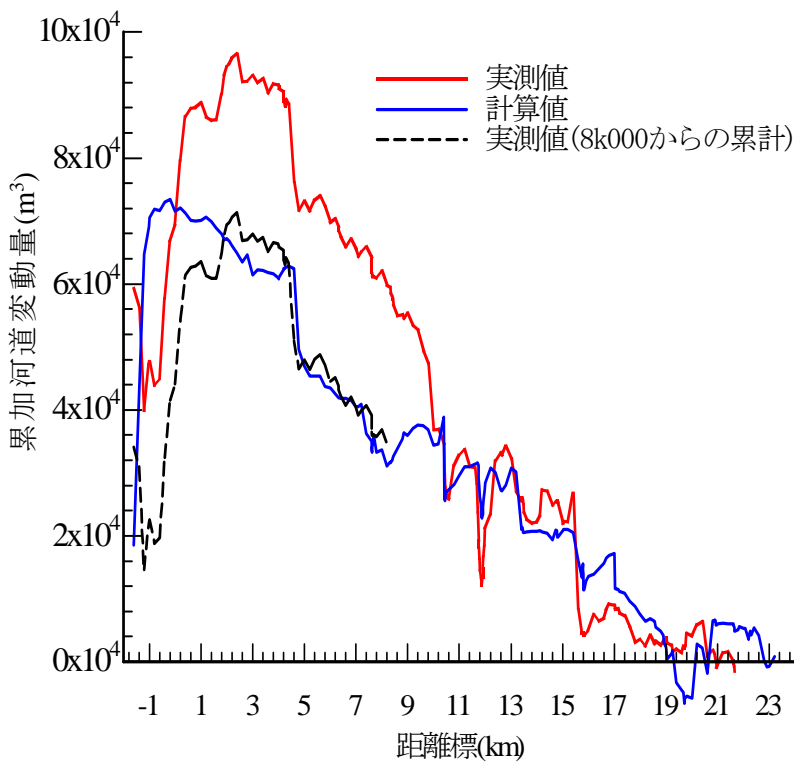

図-13 累加河道変動量

出水によって洗掘され, 下流へ堆積した河床変動 の状況を良く再現している.

謝辞 : 貴重な資料やデータを提供していただいた元山口 河川国道事務所の山本徳幸水防企画係長と資料整理に協 力して頂いた大学院生の加藤享氏に謝意を表します.

本研究は平成22年度受託研究「佐波川の堰統廃合によ る河床変動予測とその影響に関する検討」の一環として 行われたことを付記いたします。

\section{参考文献}

1) 山口大学平成21年7月21日山口防府豪雨災害調査チーム : 平 成21年7月21日山口豪雨災害調査報告書（速報版），2009.

2) 福岡 浩, 山本晴彦, 宮田雄一郎, 汪 発武, 王 功輝 : 平 成21年7月中国・九州北部豪雨による山口県防府市土砂災害, 自然災害科学, Vol.28, No.2, pp.185-201, 2009.

3) 山口河川国道事務所 : 佐波川河川モニタリング調查手法検討 報告書, 2010 .

4) 三輪-式 : 取水堰付近の堆砂問題とその対策, 第26回水理講演 会論文集，pp.69-74，1982.

5) 福岡捷二, 海野修司, 成田一郎, 辰野剛志, 西本直史 : 多摩 川二ヶ領宿河原堰の改築による堆積土砂の移動，水工学論文 集, 第48巻, pp.1081-1086, 2004.

6) 水理公式集改訂小委員会 : 水理公式集 平成11年版, p.132, 土木学会, 1999.

7) Yasuo Ishihara and Shigeki Kobatake : Runoff Model for Flood Forecasting, Bull. Disas. Prev. Res. Inst., Kyoto Univ., Vol.29, Part 1. No.260, pp.27-43, 1979.

8) 福岡捷二, 藤田光一, 新井田浩 : 樹木群を有する河道の洪水 位予測，土木学会論文集，No.447/II-19, pp.17-24, 1992.

9) 山口河川国道事務所 : 佐波川航空レーザ測量業務 業務報告 書, 2009.

10)井田至春 : 広巾員水路の定常流一断面形の影響について一, 土木学会論文集, 第69号, 別冊(3-2), 1960.

(2011. 9. 30受付) 